\title{
Analysis of three different equations for predicting quadriceps femoris muscle strength in patients with COPD*
}

\author{
Análise de três diferentes fórmulas de predição de força muscular do \\ quadriceps femoral em pacientes com DPOC \\ Aline Gonçalves Nellessen 1 , Leila Donária ${ }^{1}$, \\ Nidia Aparecida Hernandes ${ }^{1}$, Fabio Pitta1
}

\begin{abstract}
Objective: To compare equations for predicting peak quadriceps femoris (QF) muscle force; to determine the agreement among the equations in identifying QF muscle weakness in COPD patients; and to assess the differences in characteristics among the groups of patients classified as having or not having QF muscle weakness by each equation. Methods: Fifty-six COPD patients underwent assessment of peak QF muscle force by dynamometry (maximal voluntary isometric contraction of knee extension). Predicted values were calculated with three equations: an age-height-weight-gender equation (Eq-AHWG); an age-weight-gender equation (Eq-AWG); and an age-fat-free mass-gender equation (Eq-AFFMG). Results: Comparison of the percentage of predicted values obtained with the three equations showed that the Eq-AHWG gave higher values than did the Eq-AWG and Eq-AFFMG, with no difference between the last two. The Eq-AHWG showed moderate agreement with the Eq-AWG and Eq-AFFMG, whereas the last two also showed moderate, albeit lower, agreement with each other. In the sample as a whole, QF muscle weakness $(<80 \%$ of predicted) was identified by the Eq-AHWG, Eq-AWG, and Eq-AFFMG in 59\%, 68\%, and 70\% of the patients, respectively ( $p>0.05)$. Age, fat-free mass, and body mass index are characteristics that differentiate between patients with and without QF muscle weakness. Conclusions: The three equations were statistically equivalent in classifying COPD patients as having or not having QF muscle weakness. However, the Eq-AHWG gave higher peak force values than did the Eq-AWG and the Eq-AFFMG, as well as showing greater agreement with the other equations.
\end{abstract}

Keywords: Pulmonary disease, chronic obstructive; Muscle strength; Quadriceps muscle; Reference values.

\section{Introduction}

Patients with COPD exhibit functional changes in the airways and lung parenchyma, such as a chronic increase in the respiratory tract inflammatory response, an increase in inflammatory cells throughout the lung tissue, and structural changes related to the injury and repair process. ${ }^{(1,2)} \mathrm{In}$ addition to the functional changes, the disease is characterized by changes of a systemic nature, such as systemic inflammation and increased oxidative stress, nutritional changes (e.g., weight loss and wasting), and generalized skeletal muscle dysfunction. Muscle dysfunction also affects the respiratory muscles, especially the inspiratory muscles, both structurally and functionally. ${ }^{(1-4)}$
Peripheral muscle dysfunction can be defined as the loss of one of the two main properties of a muscle, which are the force-generating capacity and the endurance capacity. ${ }^{(5)}$ The dysfunction is characterized by muscle weakness, decreased muscle endurance, and fatigue. ${ }^{(3,6)}$ It is of note that these three factors can be present simultaneously. The decline in lower limb muscle strength, especially in quadriceps femoral (QF) muscle strength, has been found to be two to four times faster in COPD patients than in healthy individuals. ${ }^{(7)}$

In severe/very severe COPD, QF muscle weakness is prevalent is approximately $50 \%$ of patients. ${ }^{(8)}$ This impairment has significant clinical consequences in this population, ${ }^{(4,5,9)}$ since it is associated with

*Study carried out at the Laboratório de Pesquisa em Fisioterapia Pulmonar, Departamento de Fisioterapia, Universidade Estadual de Londrina, Londrina (PR) Brasil.

1. Laboratório de Pesquisa em Fisioterapia Pulmonar, Departamento de Fisioterapia, Universidade Estadual de Londrina, Londrina (PR) Brasil

Correspondence to: Fabio Pitta. Laboratório de Pesquisa em Fisioterapia Pulmonar (LFIP), Departamento de Fisioterapia, Avenida Robert Koch, 60, Vila Operária, CEP 86038-350, Londrina, PR, Brasil.

Tel.: 5543 3371-2477. E-mail: fabiopitta@uol.com.br

Financial support: None.

Submitted: 5 December 2014. Accepted, after review: 27 April 2015. 
low exercise tolerance, ${ }^{(10)}$ reduced quality of life, ${ }^{(11)}$ increased use of health resources, ${ }^{(12)}$ and higher mortality risk. ${ }^{(13)}$

Therefore, it is of utmost importance to assess lower limb muscle strength and to identify muscle weakness. A relatively simple, inexpensive, and easy way to quantify QF muscle strength is to assess peak force during maximal voluntary isometric contraction, which can be done by dynamometry, including with the use of a handheld dynamometer. ${ }^{(9,14)}$ It is known that lower limb muscle strength is positively related to variables such as age and body weight, and that males have greater muscle strength than females. ${ }^{(8,15)}$ In order to take these variation factors (age, weight, gender) into consideration, it is necessary to have reference values for proper interpretation of peripheral muscle strength. However, there are no global reference values for peripheral muscle strength, and the differences among the prediction equations available have not been thoroughly explored in the scientific literature.

Taking all of the above into consideration, the objective of the present study was to compare three equations for predicting peak QF muscle force: one proposed by Neder et al. ${ }^{(16)}$; one proposed by Decramer et al. ${ }^{(12)}$; and one proposed by Seymour et al.$^{(8)}$ Other objectives of this study were to determine the agreement among the equations in identifying QF muscle weakness in COPD patients and to assess the differences in characteristics among the groups of patients classified as having or not having QF muscle weakness by each of the three equations.

\section{Methods}

This cross-sectional study included 56 COPD patients who were recruited during the initial assessment of a physical training program at the State University at Londrina University Hospital, Londrina, Brazil. The criteria for inclusion in the present study were as follows: having been clinically diagnosed with COPD in accordance with the Global Initiative for Chronic Obstructive Lung Disease (GOLD) criteria ${ }^{(1)}$; being clinically stable, i.e., having had no infections or exacerbations in the previous 3 months; having no severe or unstable heart disease; having no neuromusculoskeletal changes that limited physical activities of daily living; and having had no physical training in the previous year. Patients would be excluded if they were unable to perform the tests proposed in the study.

The study was approved by the Research Ethics Committee of the State University at Londrina (Protocol no. 061/06). All participants gave written informed consent after explanation of the study procedures.

Pulmonary function was assessed with a Spirobank spirometer, version 3.6 (MIR, Rome, Italy), connected to a computer. Spirometry was performed in accordance with the American Thoracic Society/European Respiratory Society guidelines, ${ }^{(17)}$ with $\mathrm{FEV}_{1}, \mathrm{FVC}, \mathrm{FEV}_{1} / \mathrm{FVC}$ ratio, and maximal voluntary ventilation being measured. The reference values used were those for the Brazilian population. ${ }^{(18)}$

Body composition was assessed with a bioelectrical impedance device (model 310, version 5.2; Biodynamics Corporation, Seattle, WA, USA), in accordance with the protocol described by Lukaski et al. ${ }^{(19)}$ The device allows the determination of percentage of body fat, total body fat weight, fat-free mass weight, total body water, percentage of fat-free mass, and basal metabolic rate. The reference values used were those of Kyle et al. ${ }^{(20)}$ for patients with chronic respiratory failure.

Peripheral muscle strength, represented by peak isometric force of the knee extensor muscles, was assessed with the MicroFET 2 hand-held dynamometer (Hoggan Health Industries, West Jordan, UT, USA), high threshold setting. ${ }^{(21)}$ The hand-held dynamometer was attached to a multistation unit (CRW 1000; Embreex, Brusque, Brazil), and assessment occurred at a knee joint angle of $60^{\circ}$, since this is the angle at which the QF muscle produces the greatest muscle force, i.e., the angle at which the greatest torque is produced by the muscle. ${ }^{(22,23)}$ Patients were seated with their hips flexed at $90^{\circ}$, their backs supported and upright, and their hands resting on their laps (thighs; Figure 1). ${ }^{(7)}$ Assessment consisted of maximal voluntary isometric contraction of the QF (knee extension) for six seconds. A minimum of four and a maximum of ten measurements were conducted per lower limb assessed. The purpose of this variation in the number of measurements was to ensure that the value of the last measurement was not the highest during the test and that the three highest values differed by less than 5\%. The highest value was considered for analysis. ${ }^{(7)}$ The test was conducted by a trained examiner, who, during the 


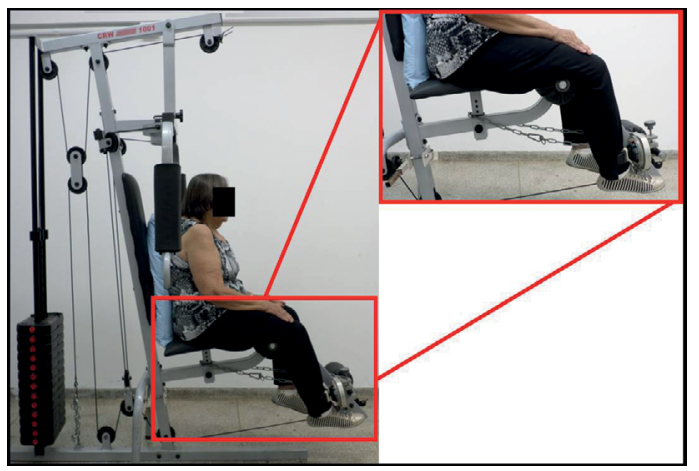

Figure 1 - Assessment of peak quadriceps femoris muscle force by measuring maximal voluntary isometric contraction of knee extension-hand-held dynamometer (MicroFET 2; Hoggan Health Industries, West Jordan, UT, USA) attached to the arm of the knee extension chair of a multi-station unit and positioned above the ankle joint of the patient's dominant limb.

maneuver, provided standardized strong verbal encouragement to patients in order to motivate them to maintain maximal effort throughout muscle contraction. The reference values used were those of Neder et al..$^{(16)}$-values derived from a sample of the Brazilian population-Decramer et al. ${ }^{(12)}$-values derived from a sample of the Belgian population (11)-and Seymour et al. ${ }^{(8)}-$ values derived from a sample of the UK population (111). Patients were classified as having QF muscle weakness $(<80 \%$ of predicted) or as not having QF muscle weakness ( $\geq 80 \%$ of predicted) on the basis of the percentage of predicted values obtained with each formula. ${ }^{(24)}$ The prediction equations are as follows:

$-1.53 \times$ age $+133 \times \mathrm{h}+0.75 \times$ weight + $34.44 \times$ gender -66.44 (1)

where age is in years, height (h) is in $m$, weight is in $\mathrm{kg}$, and gender is $1=$ male, $0=$ female .

$-2.21 \times$ age $+1.78 \times$ weight $+55.9 \times$ gender +124 (11)

where age is in years, weight is in $\mathrm{kg}$, and gender is $1=$ male, $0=$ female.

$56.2-0.30 \times$ age $+0.68 \times$ fat-free mass $0.15 \times \mathrm{h}-3.42$ (if female) (111)

where age is in years, fat-free mass is in $\mathrm{kg}$, and height (h) is in $\mathrm{cm}$.

\section{Statistical analysis}

Normality of data distribution was assessed using the Shapiro-Wilk test. Continuous variables that were normally distributed are expressed as mean and standard deviation, and otherwise as median and interquartile range (25-75\% percentile). Categorical variables are expressed as $n(\%)$.

The Friedman test with Dunn's post-test was used to compare the mean percentage of the predicted values obtained with the three equations used in the present study, whereas the chi-square test was used to compare the proportions of patients classified as having or not having QF muscle weakness by each of the three equations. An unpaired Student's t-test or Mann-Whitney test and the chi-square test (categorical variables) were used to compare characteristics among the groups of patients classified as having or not having QF muscle weakness by each of the three prediction equations. The correlation between age and the absolute and percentage of predicted values for peripheral muscle strength was tested using Pearson's or Spearman's correlation coefficients. The degree of agreement among the equations was determined using pairwise kappa statistics. ${ }^{(25)}$ The level of statistical significance was set at $p<0.05$ for all tests. The Statistical Package for the Social Sciences, version 20.0 (SPSS Inc., Chicago, IL, USA), and the GraphPad Prism software, version 6 (GraphPad Software Inc., La Jolla, CA, USA), were used for statistical analysis and graphic plotting.

\section{Results}

Table 1 describes the general characteristics of the patients included in the sample $(\mathrm{n}=$ 56). There were no exclusions. In general, the sample was characterized by moderate to very severe airway obstruction, a mean age of $66 \pm$ 9 years, and low percentage of predicted values for fat-free mass.

As expected, patients classified as not having QF muscle weakness by each of the three equations used in the present study had higher peak force values, in Newton-meter ( $\mathrm{N} \mathrm{m}$ ) and in $\mathrm{kg}$, than did those classified as having QF muscle weakness (Table 2). Patients identified with QF muscle weakness by the equations of Neder et al. ${ }^{(16)}$ and Decramer et al. ${ }^{(12)}$ were younger compared with those identified without it. Age did not correlate with the absolute values for QF muscle strength $(\mathrm{r}=-0.06, \mathrm{p}=0.7$ for $\mathrm{N} \mathrm{m}$; and $\mathrm{r}=-0.07, \mathrm{p}$ $=0.6$ for $\mathrm{kg}$ ) and correlated weakly with the percentage of predicted values obtained with 
the equations of Neder et al. ${ }^{(16)}$ and Decramer et al. ${ }^{(12)}(r=0.32, p=0.02$; and $r=0.38, p=$ 0.004 , respectively). Patients identified with QF muscle weakness by the equation of Decramer et al. ${ }^{(12)}$ had a body mass index (BMI) classified as overweight and lower percentage of predicted values for fat-free mass.

Pulmonary function (FEV in $\mathrm{L}$ ) did not correlate with the percentage of predicted values

Table $\mathbf{1}$ - General characteristics of the sample. ${ }^{\text {a }}$

\begin{tabular}{|c|c|}
\hline Characteristic & $(N=56)$ \\
\hline Gender, M/F & $33 / 23$ \\
\hline Age, years & $66 \pm 9$ \\
\hline $\mathrm{BMl}, \mathrm{kg} \cdot \mathrm{m}^{-2}$ & $26[20-30]$ \\
\hline Fat-free mass, kg & $45 \pm 10$ \\
\hline Fat-free mass, $\%$ of predicted & $66 \pm 10$ \\
\hline $\mathrm{FEV}_{1}, \mathrm{~L}$ & $1.0[0.8-1.5]$ \\
\hline $\mathrm{FEV}_{1}, \%$ of predicted & $44 \pm 17$ \\
\hline FVC, L & $2.2[1.6-2.7]$ \\
\hline FVC, $\%$ of predicted & $66 \pm 15$ \\
\hline $\mathrm{FEV}_{1} / \mathrm{FVC}, \%$ & 51 [39-67] \\
\hline GOLD, $1 / 11 / 111 / 1 V$ & $1 / 20 / 23 / 12$ \\
\hline Peak QF muscle force, $\mathrm{N} \mathrm{m}$ & $89 \pm 29$ \\
\hline Peak QF muscle force, $\mathrm{kg}$ & $29 \pm 10$ \\
\hline
\end{tabular}

M: males; F: females; BMl: body mass index; GOLD: Global Initiative for Chronic Obstructive Lung Disease; QF: quadriceps femoris; and $\mathrm{N} \mathrm{m}$ : Newton-meter. ${ }^{\mathrm{D}}$ Data expressed as absolute values, mean $\pm \mathrm{SD}$, or median [interquartile range], depending on the normality of data distribution. obtained with the equations of Neder et al., ${ }^{(16)}$ Decramer et al., ${ }^{(12)}$ or Seymour et al..$^{(8)}(r=0.05$, $p=0.7 ; r=-0.12, p=0.3 ;$ and $r=0.29, p=$ 0.03 , respectively), but correlated moderately with the absolute values for QF muscle strength $(r=0.50, p<0.001$ for $\mathrm{N} \mathrm{m}$; and $r=0.50, p$ $<0.001$ for $\mathrm{kg}$ ).

The proportion of patients identified with QF muscle weakness ( $<80 \%$ of predicted) by the equations of Neder et al., ${ }^{(16)}$ Decramer et al., ${ }^{(12)}$ and Seymour et al. ${ }^{(8)}$ was 59\%, 68\%, and $70 \%$, respectively, with no statistically significant difference (Figure 2). However, comparison of the percentage of predicted values for peak force obtained by each of the three equations showed that the equation of Neder et al. ${ }^{(16)}$ gave higher values than did the equations of Decramer et al. ${ }^{(12)}$ and Seymour et al. ${ }^{(8)}$ (75 [63-90] \% of predicted vs. 69 [56-86] \% of predicted and $67[57-86] \%$ of predicted, respectively; $p=$ 0.002 ). The percentage of predicted values for peak force obtained by the equation of Decramer et al. ${ }^{(12)}$ and those obtained by the equation of Seymour et al. ${ }^{(8)}$ were not statistically significantly different (Figure 3).

The equation of Neder et al. ${ }^{(16)}$ showed moderate agreement with the equations of Decramer et al. ${ }^{(12)}$ and Seymour et al..$^{(8)}$ (kappa $=0.66,95 \% \mathrm{Cl}: 0.42-0.82$; and $\mathrm{kappa}=0.62$,

Table 2 - Comparison of the characteristics of the groups of patients classified as having or not having quadriceps femoris muscle weakness by each of the three prediction equations used in the present study. ${ }^{\text {a }}$

\begin{tabular}{|c|c|c|c|c|c|c|}
\hline \multirow[t]{3}{*}{ Characteristic } & \multicolumn{2}{|c|}{$\begin{array}{c}\text { Equation of } \\
\text { Neder et al. }{ }^{(16)}\end{array}$} & \multicolumn{2}{|c|}{$\begin{array}{c}\text { Equation of } \\
\text { Decramer et al. }{ }^{(12)}\end{array}$} & \multicolumn{2}{|c|}{$\begin{array}{c}\text { Equation of } \\
\text { Seymour et al. }{ }^{(8)}\end{array}$} \\
\hline & $\begin{array}{l}<80 \% \text { of } \\
\text { predicted }\end{array}$ & $\begin{array}{l}\geq 80 \% \text { of } \\
\text { predicted }\end{array}$ & $\begin{array}{l}<80 \% \text { of } \\
\text { predicted }\end{array}$ & $\begin{array}{l}\geq 80 \% \text { of } \\
\text { predicted }\end{array}$ & $\begin{array}{l}<80 \% \text { of } \\
\text { predicted }\end{array}$ & $\begin{array}{l}\geq 80 \% \text { of } \\
\text { predicted }\end{array}$ \\
\hline & $(n=33)$ & $(n=23)$ & $(n=38)$ & $(n=18)$ & $(n=41)$ & $(n=15)$ \\
\hline Gender, M/F & $19 / 14$ & $14 / 9$ & $24 / 14$ & $9 / 9$ & $21 / 20$ & $12 / 3$ \\
\hline Age, years & $64 \pm 7$ & $70 \pm 9^{*}$ & $64 \pm 8$ & $70 \pm 9^{*}$ & $65 \pm 8$ & $68 \pm 10$ \\
\hline $\mathrm{BMl}, \mathrm{kg} \cdot \mathrm{m}^{-2}$ & 24 [20-30] & $26[21-30]$ & 27 [20-32] & $22[19-26]^{*}$ & $26[20-30]$ & $23[19-29]$ \\
\hline FFM, kg & $45 \pm 10$ & $45 \pm 9$ & $47 \pm 10$ & $41 \pm 8^{*}$ & $44 \pm 10$ & $47 \pm 9$ \\
\hline FFM, \% of predicted & $66 \pm 11$ & $66 \pm 9$ & $64 \pm 10$ & $70 \pm 10^{*}$ & $63[57-75]$ & $67[62-76]$ \\
\hline $\mathrm{FEV}_{1}, \mathrm{~L}$ & $1.1[0.8-1.5]$ & $1.1[0.8-1.5]$ & $1.1[0.8-1.5]$ & $1.0[0.7-1.5]$ & $1.1[0.8-1.5]$ & $1.2[0.9-1.7]$ \\
\hline $\mathrm{FEV}_{1}, \%$ of predicted & $42 \pm 15$ & $48 \pm 20$ & $44 \pm 17$ & $47 \pm 18$ & $44 \pm 16$ & $47 \pm 20$ \\
\hline FVC, L & $2[1.6-3.0]$ & $2.1[1.6-2.7]$ & $2.1[1.7-2.8]$ & $2.3[1.6-2.7]$ & $2.1[1.6-2.7]$ & $2.4[2.0-3.4]$ \\
\hline FVC, \% of predicted & $67 \pm 16$ & $67 \pm 15$ & $67 \pm 16$ & $66 \pm 14$ & $66 \pm 15$ & $68 \pm 16$ \\
\hline $\mathrm{FEV}_{1} / \mathrm{FVC}, \%$ & 50 [39-63] & 64 [40-69] & 51 [38-67] & 59 [44-67] & $52 \pm 14$ & $53 \pm 17$ \\
\hline GOLD, 1/11/111/IV & $0 / 10 / 15 / 8$ & $1 / 10 / 8 / 4$ & $0 / 14 / 14 / 10$ & $1 / 6 / 9 / 2$ & $0 / 14 / 18 / 9$ & $1 / 6 / 5 / 3$ \\
\hline Peak QF muscle force, $\mathrm{N} \mathrm{m}$ & $76 \pm 23$ & $107 \pm 27^{*}$ & $83 \pm 25$ & $100 \pm 34^{*}$ & $76 \pm 21$ & $121 \pm 20^{*}$ \\
\hline Peak QF muscle force, $\mathrm{kg}$ & $25 \pm 8$ & $35 \pm 9^{*}$ & $27 \pm 8$ & $33 \pm 11^{*}$ & $25 \pm 7$ & $40 \pm 7^{*}$ \\
\hline
\end{tabular}

M: males; F: females; BMI: body mass index; FFM: fat-free mass; GOLD: Global Initiative for Chronic Obstructive Lung Disease; QF: quadriceps femoris; and $\mathrm{N} \mathrm{m}$ : Newton-meter. ${ }^{a}$ Data expressed as absolute numbers, mean \pm SD, or median [interquartile range], depending on the normality of data distribution. ${ }^{*} \mathrm{p} \leq 0.05$ vs. $<80 \%$ of predicted. 


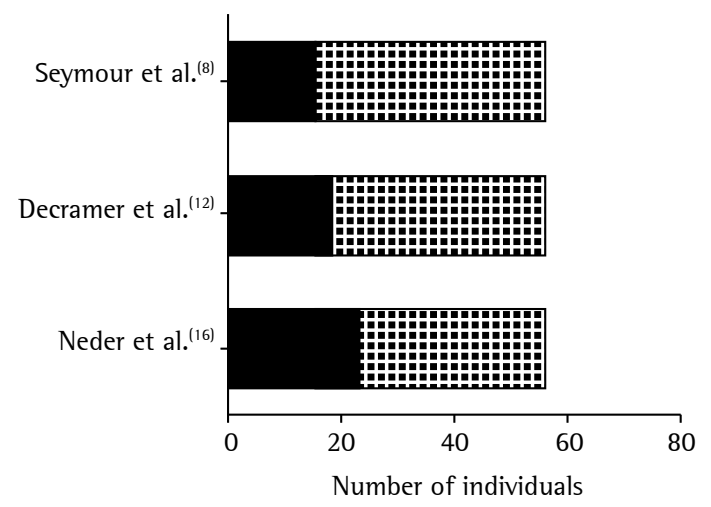

- $\geq 80 \%$ of predicted $\quad$ 㿼 $<80 \%$ of predicted

Figure $\mathbf{2}$ - Comparison of the number of patients identified with and without quadriceps femoris muscle weakness by each of the three prediction equations used in the present study.

95\% Cl: 0.41-0.83, respectively). The equations of Decramer et al. ${ }^{(12)}$ and Seymour et al. ${ }^{(8)}$ also showed moderate, albeit lower, agreement with each other (kappa $=0.52,95 \% \mathrm{Cl}: 0.28-0.76)$.

\section{Discussion}

The present study showed that the three equations studied-those of Neder et al., ${ }^{(16)}$ Decramer et al., ${ }^{(12)}$ and Seymour et al. ${ }^{(8)}$-were similar in classifying COPD patients as having or not having QF muscle weakness $(<80 \%$ of predicted and $\geq 80 \%$ of predicted, respectively). However, the prediction equation of Neder et al. ${ }^{(16)}$ gave higher percentage of predicted values for peak force than did the other two equations, as well as showing greater agreement with them.

The equation proposed by Neder et al. ${ }^{(16)}$ was derived in a study involving 96 healthy Brazilian individuals of a wide range of ages (20 to 80 years), with 15 of those 96, who had been randomly selected, being studied in each age group. Muscle strength was assessed with an isokinetic dynamometer, with the unit of measurement being $\mathrm{N}$ m. Regression analysis using this equation yields a high coefficient of determination, which explains $81 \%$ of the total variance, and the equation uses simple variables such as gender, age, height, and weight, all of which are considered to be simple, low-cost measures that can be assessed in clinical settings.

The equation proposed by Seymour et al. ${ }^{(8)}$ takes gender, age, height, and fat-free mass into

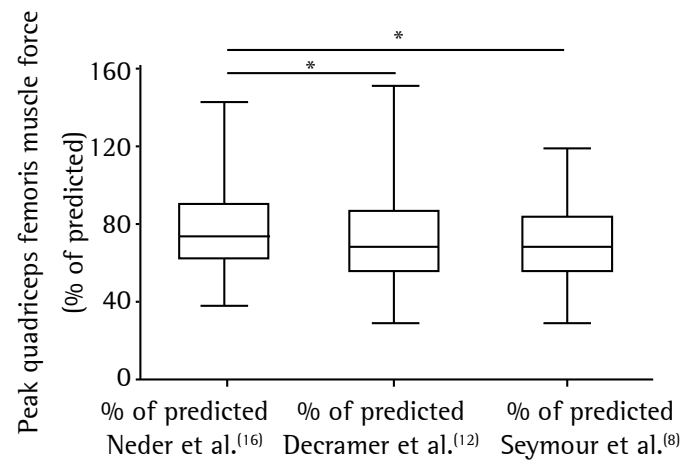

Figure 3 - Comparison of the percentage of predicted values for peak quadriceps femoris muscle force obtained with each of the three prediction equations used in the present study. ${ }^{*} p<0.002$.

consideration, which hinders its use in clinical practice because it requires the estimation of fat-free body mass (by bioelectrical impedance or dual-energy X-ray absorptiometry). The development of this equation involved the measurement of peripheral muscle strength in 212 healthy individuals between 40 and 90 years of age by using a load cell, with the unit of measurement being $\mathrm{kg}$. The age range of the sample is narrower; however, the applicability of the equation to COPD patients is appropriate, since most COPD patients are in this age group. (26) Regression analysis using this equation yields a modest coefficient of determination, which explains $50 \%$ of the total variance.

The equation proposed by Decramer et al. ${ }^{(12)}$ takes gender, age, and weight into consideration, and the unit of measurement is $\mathrm{N} \mathrm{m}$. There is little information of how this equation was derived. Data such as the number of individuals in the derivation sample, the age range of the sample, and the value of the coefficient of determination are missing, and this hinders the understanding of the applicability of the equation. The authors of that study were contacted to provide the missing data, but there was no reply.

In the present study, we found that the percentage of patients classified as having QF muscle weakness ranged from 59\% to 70\%; in contrast, the literature shows that the proportion of patients with COPD that is more severe-a population similar to that included in the present study-who have muscle weakness is approximately $50 \% .^{(7,8,15)}$ However, there is no well-established cut-off point for determining QF muscle weakness, 
and not even the most updated guidelines on peripheral muscle dysfunction in COPD patients ${ }^{(9)}$ recommend a cut-off point for presence or absence of muscle weakness. The lack of definition of what characterizes the presence of muscle weakness possibly explains this difference. In their study, Seymour et al. ${ }^{(8)}$ used another cut-off point for presence or absence of muscle weakness, but the unit of measurement used was $\mathrm{kg}$, which makes their cut-off point unsuitable for the present study, since the other equations analyzed use $\mathrm{N} \mathrm{m}$ as the unit of measurement. Patients classified as having QF muscle weakness in the present study were similar to those classified as not having it in terms of airway obstruction, GOLD $^{(1)}$ classification, and gender. Seymour et al. ${ }^{(8)}$ stated that there was no difference in the proportion of patients classified as having muscle weakness between males and females or among GOLD disease severity categories.

In the present study, the equation of Neder et al. ${ }^{(16)}$ gave higher percentage of predicted values for peak force than did the other two equations. There are clear indications that Brazilian patients with COPD perform better on the six-minute walk test and have a higher level of physical activity in their daily lives than do patients in Europe ${ }^{(27,28)}$ and even in Latin America. ${ }^{(29)}$ In addition, QF muscle strength is known to be a determinant of performance on the six-minute walk test, ${ }^{(10)}$ as well as correlating moderately with the level of daily physical activity. ${ }^{(12)}$ One can then hypothesize that QF muscle strength would also be greater in Brazilian patients than in other populations. These factors can explain why the equation of Neder et al., ${ }^{(16)}$ derived from Brazilian individuals, gave higher values in the present sample and therefore appears to be more applicable to the Brazilian population than do the equations derived from populations in other countries. This hypothesis merits further investigation; however, it is known that the reference values to be used for comparison should ideally have been derived from a population as similar as possible to the study population. ${ }^{(30)}$ The present study appears to corroborate this concept, indicating that equation of Neder et al. ${ }^{(16)}$ is the most applicable to the Brazilian population. Further studies involving other populations, such as those from which the other two equations were derived, i.e., the UK and Belgian populations, are needed to confirm that.
One possible explanation for the fact that patients classified as not having QF muscle weakness by the equations of Neder et al. ${ }^{(16)}$ and Decramer et al. ${ }^{(12)}$ were older is that, in the three equations analyzed, the multiplicative coefficient for age is negative, being lower in the equations of Neder et al. ${ }^{(16)}$ and Decramer et al. ${ }^{(12)}$ In other words, these equations predict that increasing age translates into lower muscle strength. Another factor that may explain this finding is that, although age did not correlate with the absolute values for QF muscle strength in the patients of the present study, it showed a moderate positive correlation with the percentage of predicted values obtained with the equations of Neder et al. ${ }^{(16)}$ and Decramer et al. ${ }^{(12)}$ It is of note that, in addition to having a higher BMI, patients identified with QF muscle weakness had lower fat-free mass compared with those identified without it. This is consistent with literature results that show that fat-free mass is related to lower limb muscle strength. ${ }^{(31)}$

One limitation of the present study is that the sample included only one patient with mild COPD, which can affect the generalizability of the results to this subgroup. However, patients with mild disease were not the target of this investigation, since the possibility of QF muscle dysfunction in this subgroup is lower, although it exists. Another limitation is that peak force was determined by hand-held dynamometry rather than by methods of electrical stimulation of involuntary muscle contraction or computerized dynamometry. Nevertheless, the method employed in the present study involved the use of a handheld dynamometer "attached" to an assessment chair in order to simulate the position and method of measurement of a maximal voluntary contraction performed in computerized dynamometry. This method has been shown to correlate strongly with the gold standard and is highly reproducible, ${ }^{(32)}$ as well as not affecting the measurement accuracy significantly. ${ }^{(33)}$ Finally, it was not feasible to calculate the sensitivity and specificity of each of the three equations analyzed, since there was no gold standard (or reference) method for determining the presence of muscle weakness against which to compare the equations in the present study.

The main clinical implication of the results of the present study is that they point out to physical therapists which of the equations analyzed is the 
best for identifying the presence or absence of $\mathrm{QF}$ muscle weakness in Brazilian patients with COPD, facilitating clinical practice to these professionals. The identification of muscle weakness in these patients helps physical therapists to establish the best treatment plan on a case-by-case basis.

We conclude that the three equations were statistically equivalent in classifying COPD patients as having or not having QF muscle weakness. Patients identified with QF muscle weakness by the equations of Neder et al. ${ }^{(16)}$ and Decramer et al. ${ }^{(12)}$ were younger, and patients classified as having QF muscle weakness by the equation of Decramer et al. ${ }^{(12)}$ had lower percentage of predicted values for fat-free mass and a higher BMI. The prediction equation of Neder et al. ${ }^{(16)}$ gave higher percentage of predicted values for peak force than did the other two, as well as showing greater agreement with them. These results support the recommendation that, whenever it is available (such as in Brazil), a prediction equation derived from a population as similar as possible to the target population be used.

\section{References}

1. Global Strategy for Chronic Obstructive Lung Disease [homepage on the Internet]. Bethesda: Global Initiative for Chronic Obstructive Lung Disease. [cited 2014 Sep 15]. Global Strategy for the Diagnosis, Management, and Prevention of Chronic Obstructive Pulmonary Disease; 2014 Available from: http://www.goldcopd.org/Guidelines/ guidelines-resources.html

2. Agustí AG, Noguera A, Sauleda J, Sala E, Pons J, Busquets $X$. Systemic effects of chronic obstructive pulmonary disease. Eur Respir J. 2003;21(2):347-60. http://dx.doi. org/10.1183/09031936.03.00405703

3. Miranda EF, Malaguti C, Corso SD. Peripheral muscle dysfunction in COPD: lower limbs versus upper limbs. J Bras Pneumol. 2011;37(3):380-8. http://dx.doi.org/10.1590/ S1806-37132011000300016

4. Dourado VZ, Tanni SE, Vale SA, Faganello MM, Sanchez FF, Godoy 1. Systemic manifestations in chronic obstructive pulmonary disease. J Bras Pneumol. 2006;32(2):161-71.

5. Gea J, Agustí A, Roca J. Pathophysiology of muscle dysfunction in COPD. J Appl Physiol (1985). 2013;114(9):1222-34. http://dx.doi.org/10.1152/ japplphysiol.00981.2012

6. Gea J, Orozco-Levi M, Barreiro E, Ferrer A, Broquetas J. Structural and functional changes in the skeletal muscles of COPD patients: the "compartments" theory. Monaldi Arch Chest Dis. 2001;56(3):214-24.

7. Hopkinson NS, Tennant RC, Dayer MJ, Swallow EB, Hansel TT, Moxham J, et al. A prospective study of decline in fat free mass and skeletal muscle strength in chronic obstructive pulmonary disease. Respir Res. 2007;8:25. http://dx.doi.org/10.1186/1465-9921-8-25

8. Seymour JM, Spruit MA, Hopkinson NS, Natanek SA, Man WD, Jackson A, et al. The prevalence of quadriceps weakness in COPD and the relationship with disease severity. Eur Respir J. 2010;36(1):81-8. http://dx.doi. org/10.1183/09031936.00104909

9. Maltais F, Decramer M, Casaburi R, Barreiro E, Burelle Y, Debigaré R, et al. An official American Thoracic Society/ European Respiratory Society statement: update on limb muscle dysfunction in chronic obstructive pulmonary disease. Am J Respir Crit Care Med. 2014;189(9):e1562. http://dx.doi.org/10.1164/rccm.201402-0373ST

10. Gosselink R, Troosters T, Decramer M. Peripheral muscle weakness contributes to exercise limitation in COPD. Am J Respir Crit Care Med. 1996;153(3):976-80. http:// dx.doi.org/10.1164/ajrccm.153.3.8630582

11. Mostert R, Goris A, Weling-Scheepers C, Wouters EF, Schols AM. Tissue depletion and health related quality of life in patients with chronic obstructive pulmonary disease. Respir Med. 2000;94(9):859-67. http://dx.doi. org/10.1053/rmed.2000.0829

12. Decramer M, Gosselink R, Troosters T, Verschueren M, Evers G. Muscle weakness is related to utilization of health care resources in COPD patients. Eur Respir J. 1997;10(2):417-23. http://dx.doi.org/10.1183/09031 936.97.10020417

13. Swallow EB, Reyes D, Hopkinson NS, Man WD, Porcher R, Cetti EJ, et al. Quadriceps strength predicts mortality in patients with moderate to severe chronic obstructive pulmonary disease. Thorax. 2007;62(2):115-20. http:// dx.doi.org/10.1136/thx.2006.062026

14. Robles PG, Mathur S, Janaudis-Fereira T, Dolmage TE, Goldstein RS, Brooks D. Measurement of peripheral muscle strength in individuals with chronic obstructive pulmonary disease: a systematic review. J Cardiopulm Rehabil Prev. 2011;31(1):11-24. http://dx.doi.org/10.1097/ HCR.0b013e3181 ebf302

15. Gosselink R, Troosters T, Decramer M. Distribution of muscle weakness in patients with stable chronic obstructive pulmonary disease. J Cardiopulm Rehabil. 2000;20(6):35360. http://dx.doi.org/10.1097/00008483-200011000-00004

16. Neder JA, Nery LE, Shinzato GT, Andrade MS, Peres C, Silva AC. Reference values for concentric knee isokinetic strength and power in nonathletic men and women from 20 to 80 years old. J Orthop Sports Phys Ther. 1999;29(2):116-26. http://dx.doi.org/10.2519/ jospt.1999.29.2.116

17. Miller MR, Hankinson J, Brusasco V, Burgos F, Casaburi R, Coates A, et al. Standardisation of spirometry. Eur Respir J. 2005;26(2):319-38. http://dx.doi.org/10.118 3/09031936.05.00034805

18. Pereira CA, Sato T, Rodrigues SC. New reference values for forced spirometry in white adults in Brazil. J Bras Pneumol. 2007;33(4):397-406. http://dx.doi.org/10.1590/ S1806-37132007000400008

19. Lukaski HC, Bolonchuk WW, Hall CB, Siders WA. Validation of tetrapolar bioelectrical impedance method to assess human body composition. J Appl Physiol (1985). 1986;60(4):1327-32.

20. Kyle UG, Pichard C, Rochat T, Slosman DO, Fitting JW, Thiebaud D. New bioelectrical impedance formula for patients with respiratory insufficiency: comparison to dual-energy X-ray absorptiometry. Eur Respir J. 1998;12(4):960-6. http://dx.doi.org/10.1183/090319 36.98.12040960

21. O'Shea SD, Taylor NF, Paratz JD. Measuring muscle strength for people with chronic obstructive pulmonary disease: retest reliability of hand-held dynamometry. 
Arch Phys Med Rehabil. 2007;88(1):32-6. http://dx.doi. org/10.1016/j.apmr.2006.10.002

22. Lienhard K, Lauermann SP, Schneider D, Item-Glatthorn JF, Casartelli NC, Maffiuletti NA. Validity and reliability of isometric, isokinetic and isoinertial modalities for the assessment of quadriceps muscle strength in patients with total knee arthroplasty. J Electromyogr Kinesiol. 2013;23(6):1283-8. http://dx.doi.org/10.1016/j. jelekin.2013.09.004

23. Thorstensson A, Grimby G, Karlsson J. Force-velocity relations and fiber composition in human knee extensor muscles. J Appl Physiol. 1976;40(1):12-6.

24. Sillen MJ, Franssen FM, Delbressine JM, Vaes AW, Wouters EF, Spruit MA. Efficacy of lower-limb muscle training modalities in severely dyspnoeic individuals with COPD and quadriceps muscle weakness: results from the DICES trial. Thorax. 2014;69(6):525-31. http://dx.doi. org/10.1136/thoraxjnl-2013-204388

25. Landis JR, Koch GG. The measurement of observer agreement for categorical data. Biometrics. 1977;33(1):15974. http://dx.doi.org/10.2307/2529310

26. Menezes AM, Jardim JR, Pérez-Padilla R, Camelier A, Rosa F, Nascimento O, et al. Prevalence of chronic obstructive pulmonary disease and associated factors: the PlatinO Study in São Paulo, Brazil. Cad Saude Publica. 2005;21(5):1565-73. http://dx.doi.org/10.1590/ S0102-311X2005000500030

27. Pitta F, Breyer MK, Hernandes NA, Teixeira D, Sant'Anna $\mathrm{TJ}$, Fontana AD, et al. Comparison of daily physical activity between COPD patients from Central Europe and South America. Respir Med. 2009;103(3):421-6. http://dx.doi.org/10.1016/j.rmed.2008.09.019

28. Hernandes NA, Teixeira Dde C, Probst VS, Brunetto AF, Ramos EM, Pitta F. Profile of the level of physical activity in the daily lives of patients with COPD in Brazil. J Bras Pneumol. 2009;35(10):949-56.

29. Casanova C, Celli BR, Barria P, Casas A, Cote C, de Torres JP, et al. The 6-min walk distance in healthy subjects: reference standards from seven countries. Eur Respir J. 2011;37(1):150-6. http://dx.doi. org/10.1183/09031936.00194909

30. Holland AE, Spruit MA, Troosters T, Puhan MA, Pepin V, Saey D, et al. An official European Respiratory Society/American Thoracic Society technical standard: field walking tests in chronic respiratory disease. Eur Respir J. 2014;44(6):1428-46. http://dx.doi. org/10.1183/09031936.00150314

31. Allaire J, Maltais F, Doyon JF, Noël M, LeBlanc P, Carrier $\mathrm{G}$, et al. Peripheral muscle endurance and the oxidative profile of the quadriceps in patients with COPD. Thorax. 2004;59(8):673-8. http://dx.doi.org/10.1136/ thx.2003.020636

32. Probst VS, Troosters T, Heuzel K, Van Bael J, Decramer $\mathrm{M}$, Gosselink R. Comparison of 2 devices for measuring quadriceps force in COPD patients [abstract]. Eur Respir J. 2004;24(Suppl 48):666s.

33. Stark T, Walker B, Phillips JK, Fejer R, Beck R. Hand-held dynamometry correlation with the gold standard isokinetic dynamometry: a systematic review. PM R. 2011;3(5):472-9. http://dx.doi.org/10.1016/j.pmrj.2010.10.025 